\title{
Idiopathic pulmonary hemorrhage: morphology and differential diagnosis. Case report
}

\author{
Hemorragia pulmonar idiopática: morfologia e diagnóstico diferencial. Relato de caso
}

Eduardo Cambruzzi ${ }^{1}$; Karla Lais Pêgas²; Túlio Vedana³

\begin{abstract}
Idiopathic pulmonary hemorrhage (IPH) is a rare cause of alveolar hemorrhage (AH) with unknown etiology that primarily affects children. The process has a variable clinical progression, and its diagnosis is established after excluding all causes of AH. Herein, the authors report a case of IPH in an adult male patient referring cough and hemoptysis. The conventional radiography computed tomography imaging identified zones of consolidation and areas of ground-glass attenuation in the lower lobes and lingula. Forced spirometry, bronchoscopy, and laboratorial tests yielded normal results. Several alveolar hemosiderin-laden macrophages were identified on bronchoalveolar lavage and lung biopsy. Thus, the histopathological findings associated with clinical data were compatible with IPH.
\end{abstract}

Key words: hemosiderosis; lung diseases; alveolar macrophages; pathology; hemorrhage.

\section{INTRODUCTION}

Idiopathic pulmonary hemorrhage (IPH) is a rare cause of diffuse alveolar hemorrhage whose etiology is unknown. The process, which affects primarily children, is characterized by intra-alveolar accumulation of red blood cells and hemosiderinladen macrophages. The patients present recurrent episodes of pulmonary hemorrhage, which may occasionally determine ventilatory restriction. The clinical presentation is extremely variable, and the most common symptoms include iron deficiency anemia, diffuse pulmonary infiltrates, and hemoptysis ${ }^{(3,8,10,11,25)}$.

IPH is a diagnosis of exclusion that is reached when all other causes of pulmonary hemorrhage have been ruled out. Herein, the authors report a case of IPH in a male patient referring cough and hemoptysis, and review morphological and clinical findings of this uncommon process.

\section{CASE REPORT}

Male patient, 45 years old, hairdresser, came to the hospital service referring cough and hemoptysis for twelve months. The medical history included hypertension (in daily use of enalapril $10 \mathrm{mg}$ ), sleep apnea, and previous lung infection by Haemophilus parainfluenzae. The patient denied dyspnea, chest pain, fever, smoking, frequent contact with asbestos or birds, or allergic processes. Normal pulmonary auscultation was observed at physical examination. The other organs and systems also showed no changes. Conventional chest radiography identified the presence of ill-defined opacity in the lower lobes (Figure 1). Computed tomography (CT) scan of the chest revealed the presence of zones of consolidation and patchy areas of ground-glass attenuation in the lower lobes and lingula (Figure 2). Forced spirometry showed data within normal parameters (forced expiratory volume [FEV1]: 3.75 L, forced vital capacity [FVC]: $4.81 \mathrm{~L}, \mathrm{FEV1} / \mathrm{FVC}$ : 78\%). Bronchoscopy revealed endobronchial lesions, bloody material, but pathologic secretions on bronchial lumen were not identified. The cytological examination of bronchoalveolar lavage (BAL) exhibited the presence of several vacuolated macrophages showing brown intracytoplasmic granular pigment. Bacterial, cultural, and mycological examinations of BAL were negative for the presence of fungi and/or bacteria, including Streptococcus pneumoniae and Mycobacterium tuberculosis. Moderate reflux esophagitis (grade C/Los Angeles classification) and a large

First submission on $08 / 03 / 13$; last submission on $04 / 05 / 13$; accepted for publication on $04 / 05 / 13$; published on 20/06/13

1. Post-doctorate in Cardiovascular Pathology by Instituto de Cardiologia do Rio Grande do Sul; associate professor at Universidade Luterana do Brasil (ULBRA); pathologist.

2. Master's in Pathology by Fundação da Universidade Federal de Ciências da Saúde de Porto Alegre; pathologist at Santa Casa de Porto Alegre.

3. Graduate medical student at ULBRA. 
sliding hiatal hernia were identified on upper digestive endoscopy. Doppler echocardiography examination showed the presence of altered relaxation of the left ventricle with preserved systolic performance. CT scans imaging of the abdomen revealed normal findings. The relevant laboratory tests are described in Table $\mathbf{1}$. The patient underwent biopsy (segmentectomy) of the lingula and lower basal segments of the left lung. The surgical specimen consisted of two cuneiform portions of cortical pulmonary parenchyma, which together weighed $23.0 \mathrm{~g}$ and the largest measures were $6.4 \times 2.0 \times 1.9 \mathrm{~cm}$. On gross examination, red-brownish areas of the lung parenchyma were identified. Microscopy demonstrated numerous vacuolated macrophages containing intracytoplasmic brown granular pigment (Figure 3), which occupied several alveolar spaces and alveolar ducts and some respiratory bronchioles (Figure 4). Alveolar septa did not show evidence of inflammation and/or fibrosis. Arteries, veins and capillaries also had normal appearance, without evidence of vasculitis (Figure 5). On Prussian blue stains, the intracytoplasmic granules of the alveolar macrophages proved to be hemosiderin (Figure 6). The histopathological findings related to the clinical data were then compatible with IPH. After a 60-day follow-up, including daily use of prednisone $40 \mathrm{mg}$, the patient reported a marked reduction in the frequency and intensity of hemoptysis.

TABLE 1 - IPH: clinical data

\begin{tabular}{|c|c|c|}
\hline & Result & Reference values \\
\hline Erythrocytes & 5.26 million/ul & 4.5-6.5 million/ul \\
\hline Hemoglobin & $13.9 \mathrm{~g} / \mathrm{dl}$ & $13.5-18.0 \mathrm{~d} / \mathrm{dl}$ \\
\hline Hematocrit & $42.7 \%$ & $40.0 \%-54.0 \%$ \\
\hline Mean corpuscular volume & $81.2 \mathrm{fL}$ & $76.0-96.0 \mathrm{fl}$ \\
\hline RDW & 13.9 & $11.5-16.0$ \\
\hline Leukocytes & $5,640 / \mathrm{ul}$ & $5,000-10,000 / \mathrm{ul}$ \\
\hline Lymphocytes & $1,912 / \mathrm{ul}$ & $1,000-4,000 / \mathrm{ul}$ \\
\hline Neutrophils & $3,091 / \mathrm{ul}$ & $1,500-7,000 / \mathrm{ul}$ \\
\hline Platelets & $249,000 / \mathrm{ul}$ & $130,000-400,000 / \mathrm{ul}$ \\
\hline APTT & $34 \mathrm{~s}$ & $33-43 \mathrm{~s}$ \\
\hline PT & $13.1 \mathrm{~s}$ & $13.0 \mathrm{~s}$ \\
\hline Anti-HIV & Nonreactive & Nonreactive \\
\hline Anti-HCV & Nonreactive & Nonreactive \\
\hline HBsAg & Nonreactive & Nonreactive \\
\hline HBeAg & Nonreactive & Nonreactive \\
\hline Strongyloides stercoralis (BAL) & Negative & Negative \\
\hline Cryptococcus sp. (BAL) & Negative & Negative \\
\hline Streptococcus pneumoniae antibody & Nonreactive & Nonreactive \\
\hline Rheumatoid factor & $<11 \mathrm{UI} / \mathrm{ml}$ & $<40 \mathrm{UI} / \mathrm{ml}$ \\
\hline Perinuclear antineutrophil cytoplasmic antibody & Nonreactive & Nonreactive \\
\hline Anti-GBM & Nonreactive & Nonreactive \\
\hline Antinuclear antibody & Nonreactive & Nonreactive \\
\hline Antinucleolar antibody & Nonreactive & Nonreactive \\
\hline Anticytoplasmic antibody & Nonreactive & Nonreactive \\
\hline Antimitotic apparatus antibody & Nonreactive & Nonreactive \\
\hline Antimetaphase plate antibody & Nonreactive & Nonreactive \\
\hline Creatinine & $0.93 \mathrm{mg} / \mathrm{dl}$ & $0.4-1.2 \mathrm{mg} / \mathrm{dl}$ \\
\hline Urea & $38 \mathrm{mg} / \mathrm{dl}$ & $10-50 \mathrm{mg} / \mathrm{dl}$ \\
\hline Sodium & $137 \mathrm{mEq} / \mathrm{l}$ & $135-145 \mathrm{mEq} / \mathrm{l}$ \\
\hline Potassium & $3.8 \mathrm{mEq} / \mathrm{l}$ & $3.5-5.0 \mathrm{mEq} / \mathrm{l}$ \\
\hline Calcium & $8.9 \mathrm{mg} / \mathrm{dl}$ & $8.2-10.3 \mathrm{mg} / \mathrm{dl}$ \\
\hline Uroculture & Negative for bacterial growth & Negative for bacterial growth \\
\hline C02 & $26 \mathrm{mEq} / \mathrm{l}$ & $21-32 \mathrm{mE} / \mathrm{l}$ \\
\hline TSH & $1.92 \mathrm{uUI} / \mathrm{ml}$ & $0.27-4.20 \mathrm{uUI} / \mathrm{ml}$ \\
\hline Glycemia & $91 \mathrm{mg} / \mathrm{dl}$ & $70-99 \mathrm{mg} / \mathrm{dl}$ \\
\hline Total bilirubin & $0.59 \mathrm{mg} / \mathrm{dl}$ & Up to $1.20 \mathrm{mg} / \mathrm{dl}$ \\
\hline Indirect bilirubin & $0.44 \mathrm{mg} / \mathrm{dl}$ & Up to $0.80 \mathrm{mg} / \mathrm{dl}$ \\
\hline Direct bilirubin & $0.15 \mathrm{mg} / \mathrm{dl}$ & Up to $0.40 \mathrm{mg} / \mathrm{dl}$ \\
\hline Alkaline phosphatase & $78 \mathrm{U} / 1$ & $40-129 \mathrm{U} / \mathrm{l}$ \\
\hline Albumin & $4.8 \mathrm{~g} / \mathrm{dl}$ & $3.5-\mathrm{m} 5.5 \mathrm{~g} / \mathrm{dl}$ \\
\hline Total proteins & $7.2 \mathrm{~g} / \mathrm{dl}$ & $6.0-8.0 \mathrm{~g} / \mathrm{dl}$ \\
\hline Gamma glutamyl transferase & $40 \mathrm{U} / 1$ & 8- $61 \mathrm{U} / 1$ \\
\hline Lactate dehydrogenase & $379 \mathrm{U} / \mathrm{l}$ & $240-480 \mathrm{U} / 1$ \\
\hline
\end{tabular}

IPH: idiopathic pulmonary hemorrhage; RDW: red cell distribution width; APTT: activated partial thromboplastin time; PT: prothrombin time; HIV: buman immunodeficiency virus; HCV: hepatitis C virus; HBsAg: hepatitis B surface antigen; HBeAg: hepatitis B core antigen; BAL: bronchoalveolar lavage; GBM: glomerular basement membrane antibody; CO2: carbon dioxide; TSH: thyroid stimulating hormone. 


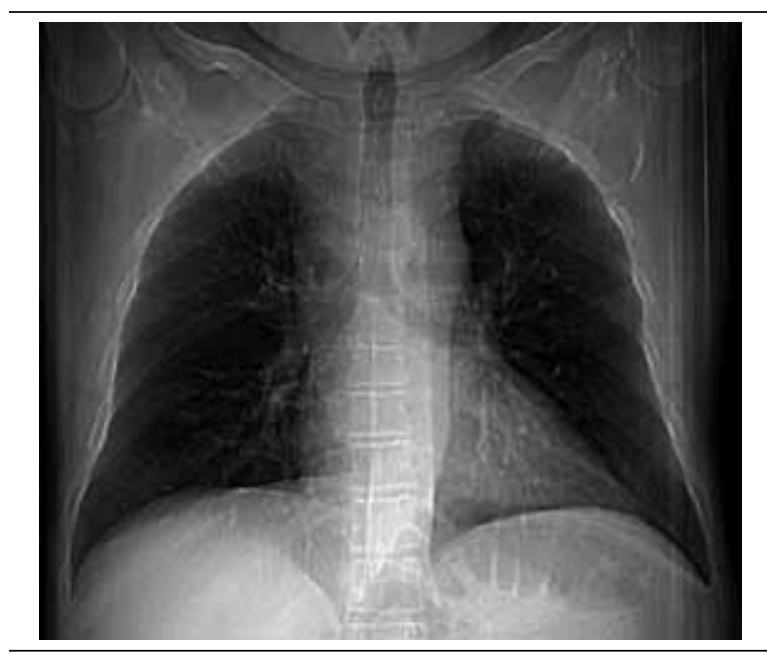

FIGURE 1 -IPH: posteroanterior chest radiographs demonstrate bilateral areas of consolidation due to pulmonary bemo rrbage IPH: idiopathic pulmonary hemorrbage.

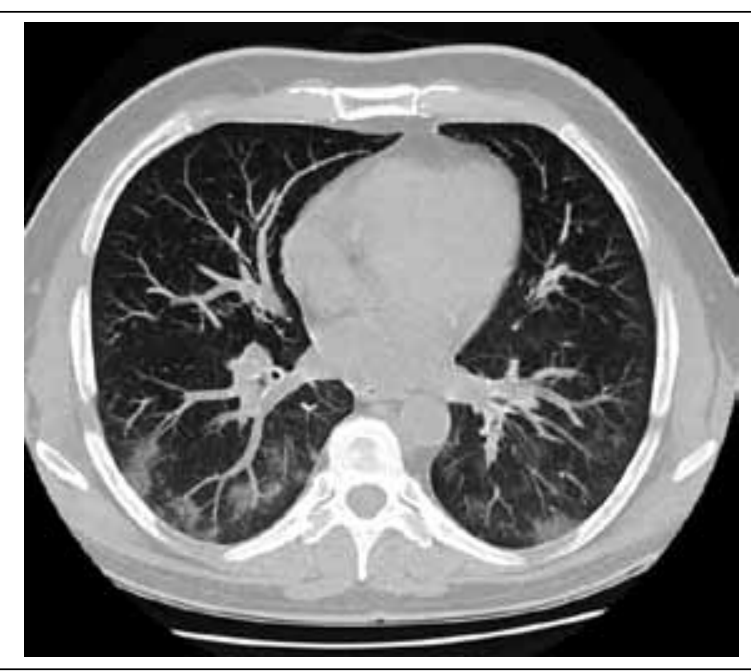

FIGURE 2 - Computed tomography through lung bases show zones of consolidation and areas of ground-glass attenuation

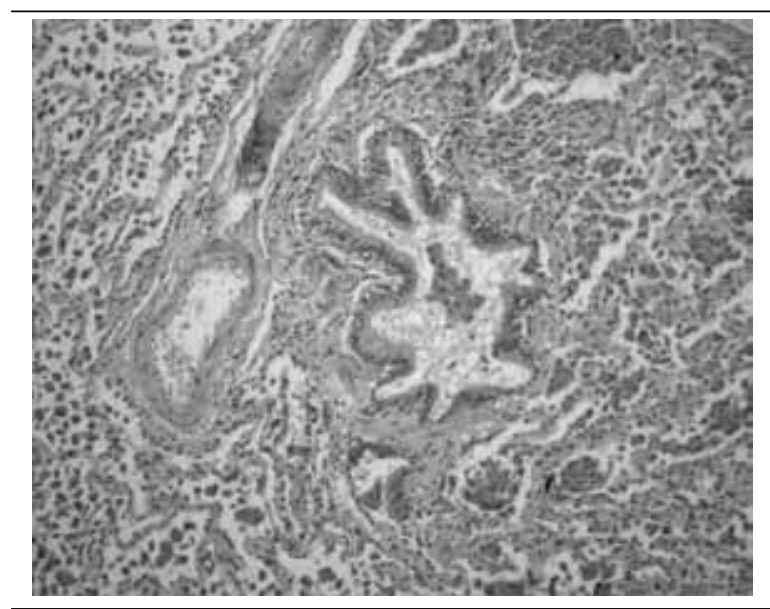

FIGURE 3 -IPH: hemosiderin-laden macrophages filling numerous alveolar spaces, without evidence of patbological changes in the wall of large blood vessels (HE 40×) IPH: idiopathic pulmonary hemorrbage; HE: hematoxylin and eosin.

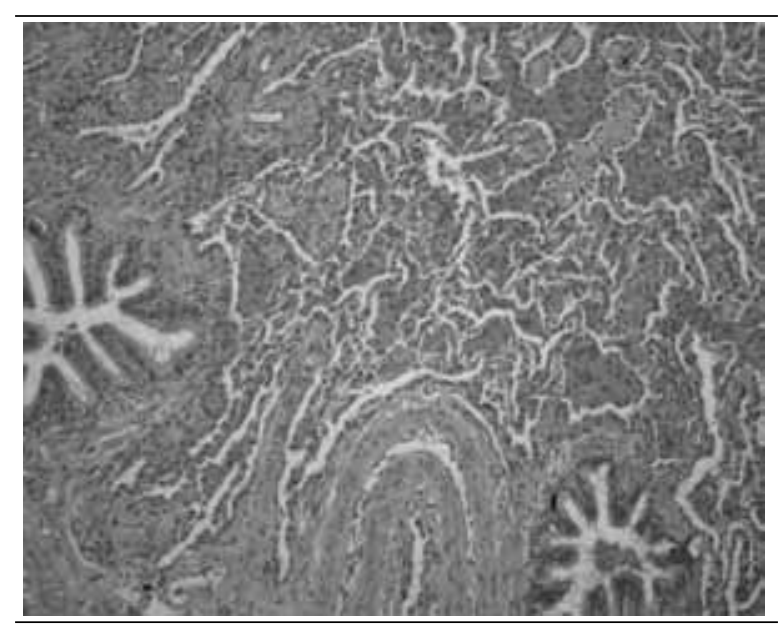

FIGURE 4 -IPH: hemosiderin-laden macrophages filling alveolar spaces, without evidence of vasculitis in small blood vessels and in alveolar septa (HE 100×) IPH: idiopathic pulmonary hemorrhage; HE: hematoxylin and eosin.

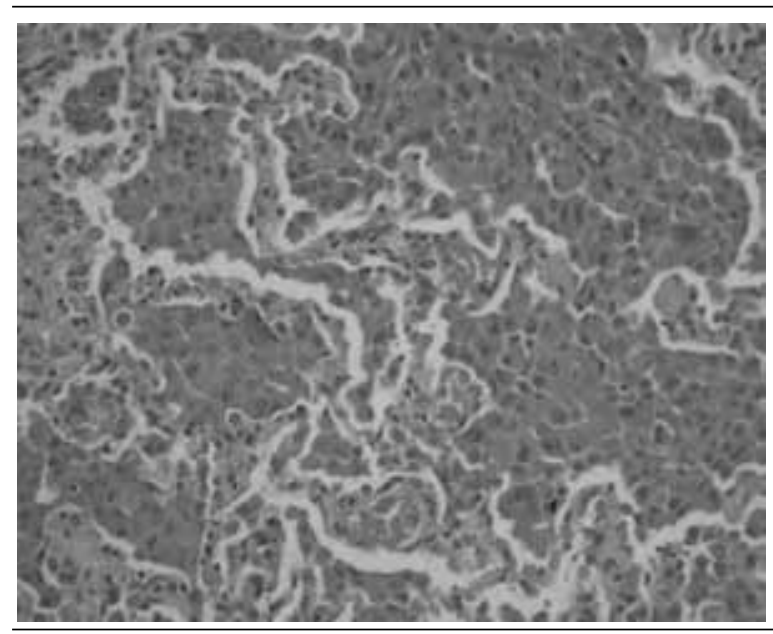

FIGURE 5 -IPH: coarse granules of brown hemosiderin are contained within the cytoplasm of numerous macrophages that fill various alveolar spaces (HE 200×) IPH: idiopathic pulmonary hemorrbage; HE: hematoxylin and eosin.

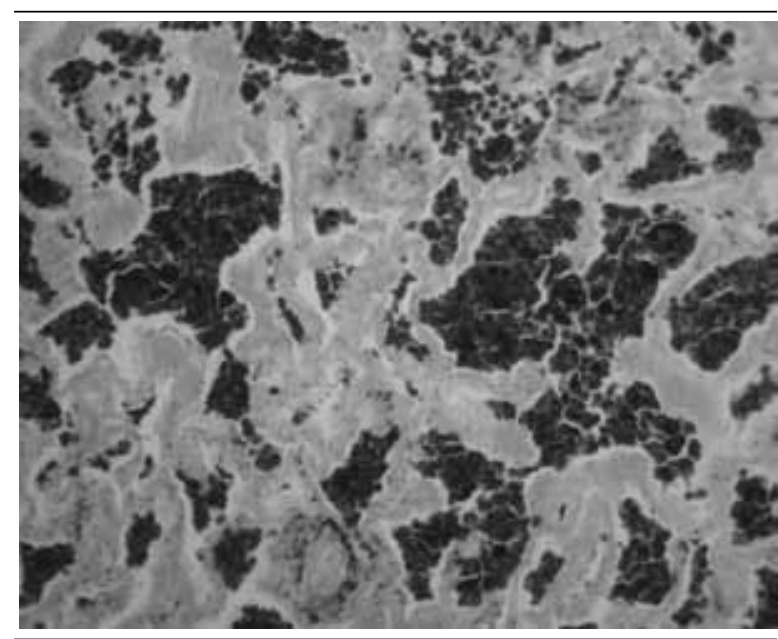

FIGURE 6 -Granules of hemosiderin can be highlighted on Prussian blue stains $(100 \times)$ 


\section{DISCUSSION}

IPH usually affects children, but in 20 percent of the patients the process is found in adults. There is no gender-based prevalence in children. The clinical presentation is most often associated with dyspnea, cough, hemoptysis, substernal chest pain, and fatigue due to iron-deficiency anemia. The episodes of pulmonary hemorrhage are recurrent and intermittent. Respiratory distress progressing to respiratory failure is uncommon. Chest examination is non-specific (crackles and consolidations). Radiographic findings of IPH consist of patchy or diffuse bilateral areas of airspace consolidation, mostly affecting the perihilar regions and lower lung zones. Zones of ground-glass attenuation may be visualized on CT scans. On gross examination, the compromised lungs show red, reddish brown, gray, or black, ill-defined areas. IPH is characterized by a diffuse acute and/or chronic hemorrhage with intra-alveolar accumulation of both red blood cells and hemosiderin-laden macrophages. Strong reaction to siderosis is observed on Prussian blue stain. Neutrophilic capillaritis may also be seen, but it tends to be mild. Long-term IPH may lead to interstitial fibrosis. By definition, IPH does not present renal involvement, immune complexes, and antineutrophil cytoplasmic antibody (ANCAS) ${ }^{(1,3,4,4,10,11,17,18,21)}$.

IPH diagnosis is made on the basis of clinical, radiologic, laboratorial and histopathological findings. Final diagnosis can be established only when any evidence of pulmonary vasculitis, nonspecific granulomatous inflammation or diseases associated with deposition of immunoglobulins have been excluded. Diffuse alveolar hemorrhage (DAH) is characterized by extensive intralveolar hemorrhage, which can be acute or chronic. The process is associated with a great variety of clinical syndromes, and most patients complain of hemoptysis. Microscopy reveals that DAH commonly presents an accumulation of intra-alveolar red blood cells and hemosiderin-laden macrophages. Specific classification of DAH syndromes requires correlation with the clinical history, laboratory results, and lung biopsy findings. The differential diagnosis of DAH may be classified immunologically by the immunofluorescence or electron microscopic findings or histologically by the data on lung biopsy. Alveolar hemorrhage (AH) may be often associated with an organizing pneumonia consisting of intra-alveolar plugs of loose, organizing fibroblastic connective tissue reminiscent of the bronchiolitis obliterans organizing pneumonia (B0OP) pattern ${ }^{(5,7,9,15,25,26)}$. Wegener'granulomatosis (WG) is a systemic granulomatous inflammatory process related to the development of vasculitis on the upper and lower respiratory tract and kidney. The major pathologic features of WG are vasculitis, parenchymal necrosis, granulomatous inflammation (mixed inflammatory infiltrate), and alveolar hemorrhage in some cases. In active generalized WG, positive staining for C-ANCA in neutrophil cytoplasm on immunofluorescence analysis is found in 84 to 99 percent of patients. Vasculitis of WG may affect arteries, veins, or capillaries in the form of

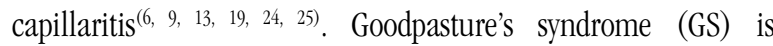
characterized by the combination of pulmonary hemorrhage with glomerulonephritis, commonly the rapidly progressive (crescentic) type. It is mediated by circulating cytotoxic antibody (generally immunoglobulin class $\mathrm{G}[\operatorname{Ig} \mathrm{G}]$ ) that reacts with pulmonary and glomerular basement membrane. Evidence of this anti-basement membrane antibody in the serum, kidney or lung biopsies is required for the diagnosis of $\mathrm{GS}^{(25)}$. Bernis et $a l .^{(2)}$ reported a case of GS remission in a female hairdresser who developed a severe anemia due to pulmonary hemorrhage followed by anti-glomerular basement membrane antibody (GBM) glomerulonephritis with normal renal function. These authors suggested that the use of products related to permanent waving could be linked with the pulmonary disease. In the present case, GS was excluded since anti-GBM and renal disease were not detected. Moreover, the histopathological findings of the sample did not demonstrate the presence of pulmonary vascular lesions or inflammatory process affecting periseptal alveolar capillaries. The authors of the present report also suggest the hypothesis, similarly to Bernis et al., that this pulmonary hemorrhage may stem from an occupational hazard. Churg-Strauss syndrome (CHS) is characterized by the presence of asthma, peripheral blood eosinophilia, neuropathy, radiographic pulmonary infiltrates, paranasal sinus abnormalities, and vasculitis. On CHS, the vascular inflammatory infiltrates are composed of chronic inflammatory cells, eosinophils, epithelioid cells, multinucleated giant cells, and/ or neutrophils. Presence of diffuse pulmonary hemorrhage and capillaritis may be seen ${ }^{(24,25)}$. Microscopic polyangiitis (MP) is a necrotizing vasculitis with few or no immune deposits that involves small vessels, showing necrotizing arteritis of small and medium sized arteries in some occasional cases. The most common lung biopsy findings in MP are pulmonary hemorrhage and neutrophilic capillaritis. On high magnification, thickening of the alveolar walls with many neutrophils on the septal interstitium can be found. The neutrophils may show karyorrhexis and fill in the surrounding alveolar spaces $(7,9,14,15,25)$. In congestive pulmonary vasculopathy, the compromised lungs show extensive and severe fibrosis of the elastic arteries. The surrounding lung tissue shows hemosiderosis ${ }^{(25)}$. Pulmonary siderosis (PS) is defined as the deposition of iron or iron oxides in the lungs after inhalation exposure. The process is more commonly found among occupational exposures. PS occurs predominantly in mining (hematite, limonite, siderite, and emery), steel mills, foundries, boiler scaling, welding, and in the grinding, polishing, and refining of metal alloys. Pure exposure 
to iron is rarely associated with clinically significant disease unless other dusts are also present, mainly silica. Microscopy reveals numerous iron-filled macrophages involving respiratory bronchioles and alveolar ducts ${ }^{20,22,27)}$. Airway disease related to mineral dust and macrophages associated with fibrosis of alveolar ducts can also be identified. The presence of silica or asbestos (mixed pneumoconiosis) modifies the pathologic findings according to the degree of this deposition. Presence of nodular fibrosis and/or centriacinar emphysema may be found in some $\operatorname{cases}^{(16,23,25,26)}$. The differential diagnosis of IPH also includes cases of vasculitis related to polyarteritis nodosa, Takayasu's arteritis, Behçet's syndrome, sarcoidosis, pulmonary infection, and septic emboli ${ }^{(4,5,7,9,11,15,17,25)}$. In the present report, the authors reported a case of IPH in an adult male patient referring cough and hemoptysis, after exhaustive clinical, laboratorial and radiologic investigation to exclude other possible causes of AH. Table 2 describes similar cases of IPH found in the international literature and comparable to the present report in relation to undetermined etiology, clinical course, and treatment.

The most frequent cause of death in IPH is related to acute respiratory failure secondary to massive hemorrhage. Chronic respiratory failure and cor pulmonale are related to the development of severe fibrosis. Some patients develop repeated episodes of hemoptysis, or persistent dyspnea and anemia ${ }^{(5,11,21,26)}$. The use of corticosteroids must be considered, but the response is variable $^{(1,3,8,12)}$. A good prognosis is expected in this case, although the possibility of short episodes of recurrence must be considered.

TABLE 2 - Summary of some published cases of IPH

\begin{tabular}{|c|c|c|c|c|c|}
\hline Authors & Age/gender & Symptoms & Radiological findings & Treatment modality & Outcome \\
\hline Allen ${ }^{(1)}$ & $19 / \mathrm{F}$ & Chest pain and dyspnea & $\begin{array}{c}\text { Bilateral interstitial } \\
\text { heterogeneous opacities }\end{array}$ & Corticosteroids & $\begin{array}{c}\text { Worsening of symptoms after } \\
\text { pregnancy }\end{array}$ \\
\hline Chen $^{(2)}$ & $50 / \mathrm{F}$ & Hemoptysis & $\begin{array}{c}\text { Diffuse alveolar bilateral } \\
\text { infiltration }\end{array}$ & Corticosteroids & $\begin{array}{l}\text { No clinical complaint after } \\
\text { one month }\end{array}$ \\
\hline Gencer $^{(7)}$ & $23 / \mathrm{F}$ & Dyspnea and cough & $\begin{array}{l}\text { Bilateral alveolar } \\
\text { infiltrates }\end{array}$ & Support care & Died during hospitalization \\
\hline Ioachimescu $^{(10)}$ & $37 / M$ & $\begin{array}{c}\text { Acute respiratory } \\
\text { insufficiency }\end{array}$ & $\begin{array}{l}\text { Areas of ground-glass } \\
\text { attenuation }\end{array}$ & $\begin{array}{l}\text { Corticosteroids and } \\
\text { azathioprine }\end{array}$ & $\begin{array}{l}\text { Occasional exacerbation of } \\
\text { disease in the last } 18 \text { years }\end{array}$ \\
\hline Kahraman ${ }^{(11)}$ & 29/M & $\begin{array}{c}\text { Fatigue, pallor, } \\
\text { hemoptysis, shortness of } \\
\text { breath, and cough }\end{array}$ & $\begin{array}{c}\text { Areas of ground- glass } \\
\text { attenuation in the lower } \\
\text { lobes }\end{array}$ & Corticosteroids & $\begin{array}{l}\text { Mild hemoptysis } \\
\text { after eight years }\end{array}$ \\
\hline Rezkalla $^{(19)}$ & $70 / \mathrm{M}$ & Hemoptysis & $\begin{array}{l}\text { Areas of consolidation in } \\
\text { both superior lobes }\end{array}$ & $\begin{array}{l}\text { Including } \\
\text { corticosteroids }\end{array}$ & $\begin{array}{l}\text { Mild hemoptysis } \\
\text { for } 40 \text { years }\end{array}$ \\
\hline Schroers $^{(21)}$ & $19 / \mathrm{F}$ & $\begin{array}{c}\text { Hemoptysis and } \\
\text { shortness of breath }\end{array}$ & Bilateral lung opacities & $\begin{array}{l}\text { Azathioprine and } \\
\text { corticosteroids }\end{array}$ & $\begin{array}{c}\text { Full disease remission } \\
\text { after } 16 \text { months }\end{array}$ \\
\hline Tzouvelekis ${ }^{(26)}$ & $27 / \mathrm{M}$ & Fever and fatigue & $\begin{array}{l}\text { Areas of ground-glass } \\
\text { opacity bilaterally }\end{array}$ & Corticosteroids & $\begin{array}{l}\text { Good clinical condition after } \\
\text { three months }\end{array}$ \\
\hline Present case & $45 / \mathrm{M}$ & Cough and hemoptysis & $\begin{array}{c}\text { Areas of consolidation } \\
\text { and ground-glass } \\
\text { attenuation }\end{array}$ & Corticosteroids & $\begin{array}{l}\text { Decrease in areas of ground- } \\
\text { glass attenuation and mild } \\
\text { to moderate hemoptysis }\end{array}$ \\
\hline
\end{tabular}

IPH: idiopathic pulmonary hemorrbage; F: female; M: male.

\section{RESUMO}

A hemorragia pulmonar idiopática (HPI) é uma causa rara de hemorragia alveolar (HA) que afeta principalmente crianças, com etiologia desconhecida. o processo tem evolução clínica variável e o diagnóstico é estabelecido depois que todas as causas de HA forem excluidas. Neste artigo, os autores relatam um caso de HPI em paciente do sexo masculino, adulto, referindo tosse e hemoptise. 0 exame radiológico convencional e a tomografia computadorizada identificaram zonas de consolidação e áreas de vidro fosco nos lobos inferiores e lingula. A espirometria forçada, a broncoscopia e os testes laboratoriais revelaram resultados normais. Numerosos macrófagos alveolares contendo hemossiderina foram identificados no lavado broncoalveolar e na biópsia pulmonar. Os achados bistopatológicos relacionados com os dados clinicos foram então compatíveis com HPI.

Unitermos: hemossiderose; doenças pulmonares; macrófagos alveolares; patologia; hemorragia. 


\section{REFERENCES}

1. ALLEN, T. K. et al. Management of a parturient with an acute exacerbation of idiopathic pulmonary haemosiderosis and posterior spinal instrumentation. Br J Anaesth, v. 100, n. 2, p. 235-9, 2008.

2. BERNIS, P. et al. Remission of Goodpasture's syndrome after withdrawal of an unusual toxic. Clin Nephrol, v. 23, n. 6, p. 312-7, 1985.

3. CHEN, C. H. et al. Idiopathic pulmonary hemosiderosis: favorable response to corticosteroids.J Chin Med Assoc, v. 71, n. 8, p. 421-4, 2008.

4. COHEN, S. Idiopathic pulmonary hemosiderosis. Am J Med Sci, v. 317, p. 67-74, 1999.

5. DE PROST, N. et al. Diffuse alveolar hemorrhage in immunocompetent patients: etiologies and prognosis revisited. Respir Med, v. 106, n. 7, p. 1021-32, 2012.

6. ESPOSITO, S. et al. Wegener's granulomatosis presenting with lifethreatening lung hemorrhage in a 7-year-old child. Rheumatol Int, v. 30 , n. 12 , p. $1665-8,2010$.

7. FISHBEIN, G. A.; FISHBEIN, M. C. Lung vasculitis and alveolar hemorrhage: pathology. Semin Respir Crit Care Med, v. 32, n. 3, p. 254 63, 2011.

8. GENCER, M. et al. Two sisters with idiopathic pulmonary hemosiderosis. Can Resp J, v. 14, n. 8, p. 490-3, 2007.

9. GROSS, W. L. et al. New perspectives in pulmonary angiitis. From pulmonary angiitis and granulomatosis to ANCA associated vasculitis. Sarcoidosis Vasc Diffuse Lung Dis, v. 17, p. 33-52, 2000.

10. IBRAHEM, R. et al. Case report of idiopathic pulmonary haemosiderosis in a child with recurrent chest infections. J Radiol Case Rep, v. 5, n. 9, p. 30-5, 2011.

11. IOACHIMESCU, 0. C. et al. Idiopathic pulmonary haemosiderosis revisited. Eur Respir J, v. 24, p. 162-70, 2004.

12. KAHRAMAN, H. et al. Eight years follow-up of a case with idiopathic pulmonary hemosiderosis after corticosteroid therapy. $N$ Am J Med Sci, v. 4, n. 1, p. 49-51, 2012.

13. LANGFORD, C. A.; HOFFMAN, G. S. Wegener's granulomatosis. Thorax, v. 54, p. 629-37, 1999 .

14. LAUQUE, D. et al. Microscopic polyangiitis with alveolar hemorrhage. A study of 29 cases and review of the literature. Groupe d'Etudes et de Recherde sur les Maladies Orphelines Pulmonaries. Medicine (Blatimore), v. 79, p. 222-33, 2000.
15. LIE, J. T. Illustrated histopathologic classification criteria for selected vasculitis syndromes. American College of Rheumatology Subcommitee on Classification of Vasculitis. Arthritis Rheum, v. 33, p. 1074-87, 1990 .

16. MCCORMCK, L. M. et al. Pulmonary fibrosis secondary to siderosis causing symptomatic respiratory disease: a case report. J Med Case Reports, v. 2, p. 257, 2008.

17. MIWA, S. et al. Prognosis in adult patients with idiopathic pulmonary hemosiderosis. Intern Med, v. 50, n. 17, p. 1803-8, 2011.

18. POGGI, V. et al. Idiopathic pulmonary hemosiderosis: a rare cause of iron-deficiency anemia in childhood.J Pediatr Hematol Oncol, v. 33, n. 4, p. 160-2, 2001

19. QIAN, Q. et al. Hemorrhagic colitis as a presenting feature of Wegener Granulomatosis. J Gastrointestin Liver Dis, v. 19, n. 4, p. 445-7, 2010.

20. REZKALLA, M. A.; SIMMONS, J. L. Idiopathic pulmonary hemosiderosis and alveolar hemorrhage syndrome: case report and review of the literature. S D J Med, v. 48, n. 3, p. 79-85, 1995

21. SANKARARAMAN, S. et al. Clinical case of the month. Idiopathic pulmonary hemosiderosis presenting as a rare cause of iron deficiency anemia in a toddler - diagnostic challenge. J La State Med Soc, v. 164, n. 5, p. 293-6, 2012

22. SCHOROERS, R. et al. A female soccer player with recurrent haemoptysis and iron deficiency aneamia: idiopathic pulmonary haemosiderosis (IPH) - case report and literature review. BMJ Case Rep, doi: 10.1136/bcr.06.2009.1969, 2010.

23. SFERLAZZA S. J.; BECKETT W. S. The respiratory health of welders. Am Rev Respir Dis, v. 143, p. 1134-48, 1991.

24. SPECKS, U.; DEREMEE, R. A. Granulomatous vasculitis. Wegener's granulomatosis and Churg-Strauss syndrome. Rheum Dis Clin North Am, v. 16, p. 377-97, 1990.

25. TRAVIS, W. D. et al. Pulmonary vasculitis. In: TRAVIS, W. D. et al. (Eds.). Non-neoplastic disorders of the lower respiratory tract - AFIP atlas of nontumor pathology. Bethesa: ARP, 2002, p. 233-58.

26. TRAVIS, W. D. et al. A clinicopathologic study of 34 cases of diffuse pulmonary hemorrhage with lung biopsy confirmation. Am J Surg Pathol, v. 14, p. 1122-5, 1990.

27. TZOUVELEKIS, A. et al. Idiopathic pulmonary hemosiderosis in adults: a case report and review of the literature. Case Reports in Medicine, v. 2012, p. 1-5, 2012.

\section{MAILING ADDRESS}

\section{Eduardo Cambruzzi}

Hospital Conceição de Porto Alegre; Avenida Francisco Trein, 596, $2^{\circ}$ andar; Laboratório de Patologia; Cristo Redentor, CEP: 91350-200; Porto Alegre-RS, Brazil; Tel.: (51) 3357-2164; e-mail: dudacambruzzi@yahoo.com.br. 